\title{
Placental development and its control in cattle
}

\author{
Jan-Dirk Haeger, Nina Hambruch and Christiane Pfarrer \\ Department of Anatomy, University of Veterinary Medicine Hannover
}

\begin{abstract}
Summary
This review aims to provide an overview of the current knowledge regarding the development and function of the bovine placenta, starting with the gross anatomical morphology and histology. In addition, detailed information on trophoblast giant cell formation (TGC) and the complex interplay of the extracellular matrix (ECM) proteins, integrins and growth factor systems is given. Drugs and pathological conditions (e.g. cloned placenta, retained placenta) are also reviewed. Knowledge derived from cell culture studies is embedded and set in proportion to the data gained from in vivo experiments. Finally, new discoveries and the major challenges for future work on the bovine placenta close the circle, in order to provide a complete picture of what is known about this fascinating, synepitheliochorial organ.
\end{abstract}

\section{Introduction}

In the bovine placenta fetal cotyledons and maternal caruncles form placentomes, which are the main areas of exchange between fetus and mother. In the past the fetal-maternal interhemal barrier was characterized as syndesmochorial, meaning that invading trophoblast is directly opposed to endometrial stroma, due to an assumed destruction of the uterine epithelium (Grosser 1927). However, subsequent studies revealed that the uterine epithelium persists throughout gestation; therefore, the term epitheliochorial placenta was proposed (Bjorkman 1969). To further specify the nomenclature, which is based on layers between fetal and maternal circulation as well as on the physiology, Wooding et al. (1992) introduced the more specific term synepitheliochorial, thus emphasizing alterations in uterine epithelium by hybrid cell formation (Wooding 1992). To date, this specification is generally accepted.

Like other mammalian species, diseases compromising the placenta and its function are also present in bovine. One of the most prominent is the retention of fetal membranes (RFM), which can affect the reproductive performance and lead to considerable economic loss at the herd level (Laven \& Peters 1996). Even though in the past numerous attempts were made to tackle this pathology by using a variety of sophisticated methodologies (e.g. gene expression analysis),

Corresponding author E-mail: Christiane.Pfarrer@tiho-hannover.de

Dedicated to Prof. Dr. Rudolf Leiser for sharing with me his contagious excitement for bovine placentation and mentoring my scientific career without restricting my creativity. 
RFM still remains a major economic problem. This review attempts to give a comprehensive overview of the development of the bovine placenta including placental morphology, trophoblast development, cell-cell and cell-matrix interactions, new discoveries and major future challenges. In addition to in vivo data that is available, we chose to incorporate a range of findings from in vitro studies since it has become more and more popular to use cell-culture based systems to investigate distinct, isolated aspects of placental development or functionality in a controlled environment.

\section{General morphology}

In the mature placenta of cattle, groups of (fetal) chorioallantoic villi, named cotyledons, are anchored in maternal endometrial crypts, which are part of the caruncle. Each fetal villus contains an outer trophoblast layer, underlined by mesenchyme containing multiple blood vessels. The outermost uterine cell layer, neighboring the trophoblast, is the uterine epithelium, which is also underlined by stromal tissue and multiple blood vessels (Buse et al. 2013). Fetal villi themselves can be divided into stem, intermediate and terminal villi, whilst the villous blood vessels can be accordingly classified as stem arteries and veins, intermediate arterioles and venules and terminal capillaries. This cotyledonary architecture of the fetal placenta is like the one found in the human hemochorial placenta (Leiser et al. 1997). Interestingly, the villous placental blood vessels of ruminants show adaptational changes to hypoxic environmental stress, analogous to changes occurring in placentas of e.g. heavy smokers (Krebs et al. 1997, Pfarrer et al. 1999). During bovine implantation the chorioallantoic sac enlarges from gestational day (gd) 16 to 27 (for review (Assis Neto et al. 2010). Within this period the development of cotyledons starts near to the embryo and later spreads over the chorioallantoic sac. Exclusively the allantochorion of the cotyledons attaches to the uterine caruncles forming so-called placentomes. Due to this sequential formation the most developed placentomes can be found close to the embryo (Leiser 1975). The caruncles themselves number up to 100 to 140 and are devoid of endometrial glands. In the nonpregnant animal the caruncular precursors are mushroom-shaped nodules that have already been observed in fetal endometrium and undergo histological remodeling up to 12 months after birth in order to become caruncles (Atkinson et al. 1984). During implantation and placentation in cattle major structural and ultrastructural changes occur (Wathes \& Wooding 1980, Leiser 1975), which finally lead to the mature bovine placenta. Actual growth is observed until gd 170; after that enlargement of the feto-maternal interface is accomplished by branching of the villous trees and corresponding crypts (Leiser et al. 1997). Histologically, the synepitheliochorial ruminant placenta contains $80 \%$ polarized uninucleate trophoblast cells (UTC) and 20\% non-polarized trophoblast giant cells (TGC). Like the UTC the uterine epithelium (UE) is also polarized. Both cell layers possess apical microvilli, which lie in close association with each other. The remaining gap is termed intervillous space. In epitheliochorial and synepitheliochorial placentae this space is $15-20 \mathrm{~nm}$ wide and contains ancient pregnancy-associated glycoproteins (Wooding et al. 2005b). In the synepitheliochorial placenta of sheep extracellular matrix (ECM) proteins like osteopontin are distinctly located in the intervillous space and have been suggested to mediate trophoblast attachment to the endometrium (Johnson et al. 2003). The gross anatomy and histology of the bovine placenta at different developmental stages are shown in Fig. 1. 


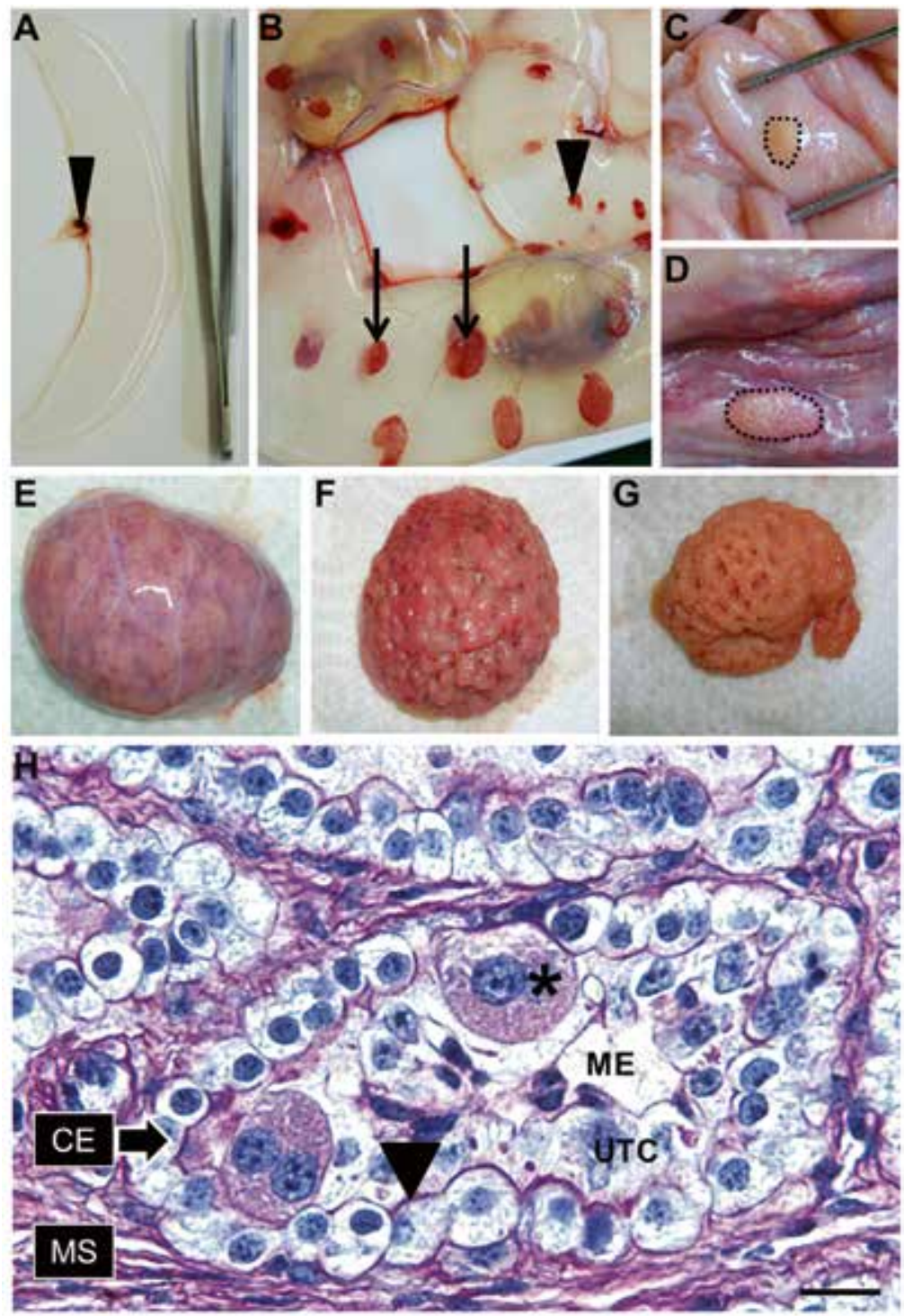

Fig. 1. Gross anatomy of different developmental stages of the bovine placenta (A-G) and histology of the feto-maternal interface in cattle $(\mathrm{H})$.
All samples were obtained from the local abattoir and the gestational day (GD) was determined according to (Assis Neto et al. 2010). (A) Early stage of bovine placental development: no cotyledons on the chorioallantoic sac (CAS) (length: $14 \mathrm{~cm}$, width: $0.7-$ $1.4 \mathrm{~cm})$ are visible. The size of the embryo (GD 16-17) (thin arrowhead) is $0.8 \mathrm{~cm}$. (B) More advanced stages of bovine placenta: multiple cotyledons (caliber: 2-2,2cm) (pars fetalis of placenta) can be seen on the CAS. The most developed are close to the embryo (GD 28) (arrows), whilst the least developed are located at the end of the CAS (arrowheads). The size of the embryo is $8 \mathrm{~cm}$. The images (C) and (D) display endometrial caruncles (pars maternalis of placenta) close to the embryo, which have been indicated by dotted lines. (C) Caruncle (calibre: $0.5 \mathrm{~cm}$ ) in early pregnancy belonging to the embryo in image (A). No crypts are observed. (D) Caruncle (calibre: $1-1.3 \mathrm{~cm}$ ) belonging to the embryos in image (B): shallow caruncular crypts can be seen. (E-G) Bovine midgestational placentome (5.-6. month of gestation; size $4-4.4 \mathrm{~cm}$ ). (E) Intact

placentome (partes fetalis and maternalis). On the fetal side chorioallantoic blood vessels supplying the cotyledon are visible. (F-G) The same placentome separated: a cotyledon (F) containing multiple fetal villi that were formerly anchored in the crypts of the maternal caruncle $(\mathrm{G})$. $(\mathrm{H})$ Histological section stained with PAS (Periodic Acid Schiff): The core of the fetal villus is made up of mesenchyme (ME) lying beyond the uninucleate trophoblast (UTC), located on a basement membrane. Among the UTC two trophoblast giant cells (asterisks) can be seen, one of which is binucleate. The caruncular epithelium (CE) itself is located on a basement membrane and is underlined by maternal stroma (MS). The feto-maternal interface (between UTC and CE) is partially strongly stained (arrowhead). Scale bar $=20 \mu \mathrm{m}$. 


\section{Trophoblast Giant Cells (TGC)}

TGC (Klisch et al. 1999a) are considered to be moderately invasive (Pfarrer et al. 2003) because they migrate through chorionic tight junctions towards the UE and fuse with singular UE to form hybrid cells, which exocytose TGC products into the maternal compartment of the placenta. Due to the fact that the majority of TGC have two nuclei they are also termed binucleate cells (BNC) or in older literature diplokaryocytes. They arise from uninucleate trophoblast cells (UTC) (Wimsatt 1951) by tripolar acytokinetic mitosis and are polyploid (Klisch et al. 1999ab). TGC begin to form during bovine implantation from gd 16-33 (Wathes \& Wooding 1980, Leiser 1975, Greenstein et al. 1958) and make up $20 \%$ of all trophoblast cells throughout gestation (Wooding 1992). Their number decreases dramatically at the end of gestation, when TGC can only be sporadically detected in individual villi (Klisch et al. 2006). In cattle hybrid cells generally form through fusion of one TGC with one uterine epithelial cell, and therefore mostly contain three nuclei. In contrast, ovine TGC continuously fuse with existing hybrid cells, thereby forming syncytia with up to 25 nuclei (Wooding 1992). The fact that the ovine feto-maternal interface almost exclusively consists of these large hybrid syncytia may be one reason that RFM is not common in sheep. In past studies it was discussed whether or not TGC could arise from all UTC or exclusively from a stem cell population (Greenstein et al. 1958, Wimsatt 1951). The mature placenta in rodents is known to have multiple TGC subtypes that have distinct cell lineage origins (Hu \& Cross 2010). Apart from that, murine TGC that differentiate from trophoblast stem cell lines showed invasive capacity thereby resembling normal trophoblast cells in vivo (Hemberger et al. 2004). In bovine, little is known about the stages of differentiation from a uninucleated trophoblast cell (UTC) to an invading TGC or the underlying reasons for the drastic change in biological activity between these two cell populations. Trophoblast cell lines provide valuable data for investigating this process, which is one of the most intriguing characteristics of trophoblast cells. A common feature of blastocyst (Shimada et al. 2001) and placenta-derived bovine trophoblast cells in culture (Hambruch et al. 2009) is the loss of TGC, most likely because no more UTC undergo TGC differentiation in vitro (Shimada et al. 2001, Hambruch et al. 2009). Yet, singular TGC, which have either attached or spontaneously differentiated, can be seen in early passages of bovine primary (Hambruch et al. 2009) or permanent trophoblast cell lines (Hambruch et al. 2009, Shimada et al. 2001). The loss of TGC and the continuous presence of proliferating UTC, from which TGC in vivo originate, makes such cell lines an ideal tool to study TGC differentiation and possibly identify its regulators. Different conclusions have been drawn from such in vitro experiments. Nakano et al. (2002b) have demonstrated that extracellular matrix, namely type I collagen (COL1) could induce up to $3 \%$ TGC from blastocystal UTC. The resulting TGC showed expression of bovine placental lactogen (bPL, CSH1), no cytokeratin expression, and polyploid nuclei (Nakano et al. 2002b). Yet, the expression of pregnancyassociated glycoproteins and the total in vivo TGC percentage (20\% of all trophoblast cells) has not been observed (Nakano et al. 2002b, Nakano et al. 2002a), indicating differentially regulated steps in TGC differentiation. UTC isolated from bovine placentomes so far have not been shown to differentiate into TGC (Hambruch et al. 2009). One reason could be the fact that the UTC placental environment (polarized cells with apical contact to uterine epithelial cells after epithelial-mesenchymal transformation) is completely different from the preimplantative blastocystal one. In addition, the co-localization of transcription factors in bovine trophoblast cells in vivo has pointed towards the importance of proteins like DLX3 (distal-less homeobox 3), SP1 (specificity protein 1) and PPARG (peroxisome proliferator-activated receptor gamma; Degrelle et al. 2011) in the regulation of TGC formation. Other transcription factors like OCT4 (octamer-binding transcription factor 4), NANOG and CDX2 (caudal type homeobox 2) have only been analyzed during the development of blastocyst stage embryos (Madeja et al. 2013) 
in vitro but not in placental tissue. Yet, others like GATA2 and GATA3 (GATA binding protein 2/3) have been found to affect endogenous CDX2 and INFT (interferon tau) expression (Bai et al. 2009) and might also play a role in TGC development. Multiple growth factors like Fibroblast Growth Factor (FGF) (Pfarrer et al. 2006a), Vascular Endothelial Growth Factor (VEGF) (Pfarrer et al. 2006b) and Platelet-Activating Factor (PAF) (Bucher et al. 2006) are co-localized in TGC and could act upstream of the previously mentioned transcription factors. In addition, others have suggested that steroid synthesis could be the most striking cause for TGC differentiation (Schuler et al. 2008, Khatri et al. 2013). Furthermore, another hypothesis on the development of TGC has been proposed, namely endogenous retroviruses, which are latently present in the mammalian genome (Black et al. 2010, Koshi et al. 2012). Such retroviral genes have been detected in the bovine placenta in vivo (Baba et al. 2011) and in vitro where they are involved in the expression of TGC-specific genes during the differentiation process (Koshi et al. 2011, Koshi et al. 2012).

\section{Cell-cell and cell-matrix interactions}

Caruncular and placentomal growth, elaboration of villous trees as well as regression after birth requires extensive tissue remodeling during all stages of gestation and postpartum. Any remodeling is based on loosening/dissociation of cell-matrix junctions within the connective tissue of the maternal crypts and the fetal mesenchyme of the villous trees. Here fibroblasts are the major source for ECM molecules like fibronectin (FN1), type I collagen and type IV collagen (COL4) and laminin. They also produce a variety of matrix metalloproteinases (MMPs) for the remodeling of those components (Kalluri \& Zeisberg 2006). In bovine, ECM molecules have been detected in the placenta from gestational day (gd) 80 to 270 in addition to the subunits of their respective integrin receptors (Pfarrer et al. 2003). These integrins are known to serve multiple functions at the feto-maternal interface in domestic animals during implantation (Burghardt et al. 2002). MMPs are a family of zinc-dependent endopeptidases that collectively are capable of degrading all extracellular matrix molecules. The MMP family can be subdivided into four different groups, which are the archetypal MMPs like collagenases, the gelatinases (e.g. MMP9), the matrilysins and the convertase-activatable MMPs (e.g. MMP14) that can be secreted or are membrane-associated (Fanjul-Fernandez et al. 2010). MMPs are regulated by four specific tissue inhibitors of matrix metalloproteinases (TIMPs) and by a variety of growth factors, cytokines and chemokines (Clark et al. 2008). Furthermore, MMPs cleave intracellular substrates like cytoskeletal proteins and are located in multiple cellular compartments, demonstrating the importance and wide range of MMP mediated processes (Cauwe \& Opdenakker 2010). Placental cells share many molecular circuits with cancer cells (Ferretti et al. 2007). Specifically, the biological activities of MMPs (e.g. for cell proliferation, invasion and angiogenesis) have been confirmed for cancer cells (Egeblad \& Werb 2002, Murray \& Lessey 1999). Therefore, in the placenta similar ways of action are likely during implantation, gestation and around parturition.

Several studies have detected MMPs and tissue inhibitors of metalloproteinases (TIMPs) in bovine placental tissue throughout gestation (Kizaki et al. 2008, Walter \& Boos 2001) or at term in comparison to animals suffering from RFM (Dilly et al. 2011, Streyl et al. 2012, Walter \& Boos 2001). The gelatinases MMP2 and 9 are located in multiple placental compartments and appear to be the most likely candidates to play roles in ECM remodeling throughout gestation (Walter \& Boos 2001, Kizaki et al. 2008). In term placental tissue membrane-bound MMP14 was also expressed on a protein level (Dilly et al. 2011). The main TIMP expressed in the placenta on a protein level is TIMP2, which is distinctly located only in TGC (Walter \& 
Boos 2001, Dilly et al. 2011). Furthermore, the mRNA of extracellular matrix metalloproteinase inducer (EMMPRIN), another factor that is able to regulate MMP14 and 2 expression, was located in bovine placental cell populations in increasing quantities throughout gestation (Mishra et al. 2012). Other members of the MMP (MMP1, 3, 9, 13, and 16) and TIMP family (TIMP1, 3 and 4) have so far only been detected on an mRNA level (Streyl et al. 2012) in term placental tissue, apparently due to the lack of proper antibodies.

Regarding the localization of ECM molecules and MMP substrates, considerable data are available. Throughout gestation multiple ECM molecules have been detected in the bovine placenta (Pfarrer et al. 2003, Boos et al. 2000). In placentomes, type I collagen and type III collagen are localized in the mesenchyme and the endometrial maternal stroma as well as blood vessel walls, while type IV collagen is observed beneath all epithelia, myometrium and also in the walls of vessels. Interestingly, type I collagen cannot be observed in the mesenchyme during early pregnancy, but later on increases strongly in midpregnancy (Boos et al. 2003b). The walls of large fetal and maternal blood vessel continuously express fibronectin and laminin throughout gestation. At gd 270 a local loss of type IV collagen and laminin has been observed in the maternal basement membrane. During early pregnancy TGC express high amounts of laminin and the corresponding ITGA6B1 integrin receptor homogeneously in the cytoplasm, suggesting TGC invasion along a self-produced matrix. Later on (gd 220-270) this localization shifts to a membrane-associated one. The expression of various integrin receptors throughout gestation has also been examined within the bovine placenta (Pfarrer et al. 2003). Molecules of the ECM and its corresponding integrin receptors have also been localized in bovine endometrium during the estrous cycle (Boos, 2000) and during bovine implantation in endometrium and trophoblast (Maclntyre et al. 2002, MacLaren \& Wildeman 1995). In cattle TGC fusion with uterine epithelium (UE) during implantation has been proposed as being capable of changing the integrin/ECM composition of the subepithelial, endometrial stroma (Maclntyre et al. 2002). A distinct local change of stromal ECM (type I collagen content) upon implantation has been observed in goats (Guillomot 1999). In cattle, conflicting data on type I collagen downregulation in the subepithelial endometrial stroma in early pregnancy and/or the end of the cycles exist (Yamada et al. 2002, Boos, 2000), Due to the known extensive crosstalk of cell associated integrins with ECM proteins and many other growth factors and cytokine receptors such alterations are to be expected. For example, growth factor signaling affects the expression of a variety of molecules like MMP, TIMP, integrins and extracellular matrix molecules (ECM) during the establishment of human pregnancy (McEwan et al. 2009). In the bovine placenta multiple growth factor systems have been detected in the bovine placenta like FGF (Pfarrer et al. 2006a), VEGF (Pfarrer et al. 2006b), PAF (Bucher et al. 2006), EGF, Amphiregulin and Neuroregulin (Akbalik \& Ketani 2013), Insulin-like growth factor (Ravelich et al. 2004) and Transforming growth factor $\beta$ (TGFB) (Ravelich et al. 2006, Sugawara et al. 2010). Others, like bone morphogenetic protein (BMP) were found only in the bovine trophectoderm prior to uterine attachment (Pennington \& Ealy 2012). In this context the relevance of the ECM should be highlighted again, since it plays a crucial and complex role during growth factor signaling. The ECM proteins are able to bind a great variety of soluble growth factors thereby regulating their bioavailability and integrating multivalent signals to the cell in a timely and spatially organized manner (Taipale \& Keski-Oja 1997). To gain insights into the mechanistic aspects of how such growth factor systems could potentially influence MMP, TIMP, ECM molecules or integrin expression in bovine placental cell, in vitro studies were undertaken in the past. Such studies used bovine endometrial stroma cells and bovine blastocyst (Hirata et al. 2003b) or placental trophoblast cells (Dilly et al. 2010) and observed that growth factors like EGF, tumor necrosis factor (TNF) or ECM molecules like type I collagen, affect the expression of components of the MMP/TIMP system (Dilly et al. 2010, Hirata et al. 2003a, Hirata et al. 2003b). The maternal and fetal localization of proteins in the bovine placenta is shown in Table 1. 
Table 1. Distribution pattern of proteins in bovine placentomal tissue over the course of implantation and gestation (analyzed by immunohistochemistry)

\begin{tabular}{|c|c|c|c|c|c|c|c|c|c|c|c|}
\hline \multirow{2}{*}{$\frac{\text { Protein }}{\text { ECM }}$} & \multicolumn{4}{|c|}{ Maternal Localisation } & \multicolumn{5}{|c|}{ Fetal Localisation } & \multirow[b]{2}{*}{ time frame } & \multirow[b]{2}{*}{ Ref. } \\
\hline & MS & $\mathrm{ME}$ & MBM & $\mathrm{MV}$ & FS & UTC & FBM & TGC & $\mathrm{FV}$ & & \\
\hline Coll-1 & $x$ & $x$ & $\mathrm{~nm}$ & $\mathrm{~nm}$ & $\mathrm{~nm}$ & $x$ & $\mathrm{~nm}$ & $\mathrm{~nm}$ & $\mathrm{~nm}$ & gd $0-30$ & Yamada et al. 2002 \\
\hline Coll-1 & $x$ & $\mathrm{~nm}$ & $\mathrm{~nm}$ & $x$ & $x^{1,2}$ & $\mathrm{~nm}$ & $\mathrm{~nm}$ & $\mathrm{~nm}$ & $x^{1,2}$ & gm 1-9 & Boos et al. 2003b \\
\hline Coll-1 & $x$ & - & $x$ & $x$ & - & - & - & - & - & gd 80-270 & Pfarrer et al. 2003 \\
\hline Coll-III & $x$ & $\mathrm{~nm}$ & $\mathrm{~nm}$ & $x$ & $x^{2}$ & $\mathrm{~nm}$ & $\mathrm{~nm}$ & $\mathrm{~nm}$ & $x^{2}$ & gm 1-9 & Boos et al. 2003b \\
\hline Coll-IV & $\mathrm{nm}$ & $\mathrm{nm}$ & $x$ & $\mathrm{~nm}$ & $\mathrm{~nm}$ & $\mathrm{~nm}$ & $x$ & $\mathrm{~nm}$ & $\mathrm{~nm}$ & $\operatorname{gd~0-30}$ & Yamada et al. 2002 \\
\hline Coll-IV & $x$ & $\mathrm{~nm}$ & $x$ & $x$ & $x$ & $\mathrm{~nm}$ & $x$ & $\mathrm{~nm}$ & $x$ & gd 18-30 & Macintyre et al. 2002 \\
\hline Coll-IV & $x$ & $\mathrm{~nm}$ & $x$ & $x$ & $x$ & $\mathrm{~nm}$ & $x$ & $\mathrm{~nm}$ & $x$ & gm 1-9 & Boos et al. 2003b \\
\hline Coll-IV & $x$ & - & $x^{3}$ & $x$ & $x$ & $x$ & $x$ & - & $\mathrm{x}$ & gd 80-270 & Pfarrer et al. 2003 \\
\hline $\mathrm{FN}$ & $x$ & $x$ & $\mathrm{~nm}$ & $\mathrm{~nm}$ & $\mathrm{~nm}$ & $x$ & $\mathrm{~nm}$ & $\mathrm{~nm}$ & $\mathrm{~nm}$ & gd 0-30 & Yamada et al. 2002 \\
\hline $\mathrm{FN}$ & $x$ & $\mathrm{~nm}$ & $\mathrm{~nm}$ & $\mathrm{~nm}$ & $\mathrm{~nm}$ & - & - & - & $\mathrm{nm}$ & gd 14-21 & MacLaren \& Wildeman 1995 \\
\hline FN & $x$ & - & $x$ & $x$ & $x$ & $x$ & $x$ & $\cdot$ & $x$ & gd 80-270 & Pfarrer et al. 2003 \\
\hline LAMA & $\mathrm{nm}$ & $x$ & $x$ & $x$ & $\mathrm{~nm}$ & $x$ & $x$ & $\mathrm{~nm}$ & $x$ & gd 0-30 & Yamada et al. 2002 \\
\hline LAMA & $x$ & $\mathrm{~nm}$ & $x$ & $x$ & $x$ & $\mathrm{~nm}$ & $x$ & $\mathrm{~nm}$ & $x$ & gd 18-30 & Macintyre et al. 2002 \\
\hline LAMA & $x$ & - & $x^{3}$ & $x$ & - & - & - & $x$ & - & gd $80-270$ & Pfarrer et al. 2003 \\
\hline Integrins & MS & ME & MBM & MV & FS & UTC & FBM & TGC & $\mathrm{FV}$ & time frame & Ref. \\
\hline alpha1 & $x$ & $x$ & $\mathrm{~nm}$ & $\mathrm{~nm}$ & $\mathrm{~nm}$ & $x$ & $\mathrm{~nm}$ & $\mathrm{~nm}$ & $\mathrm{~nm}$ & gd 18-30 & Maclntyre et al. 2002 \\
\hline alpha1 & $\mathrm{x}$ & - & - & $x$ & $x$ & - & - & - & $x$ & gd $80-270$ & Pfarrer et al. 2003 \\
\hline alpha2 & $x$ & - & - & $x$ & $x$ & - & - & $x$ & $x$ & gd 80-270 & Pfarrer et al. 2003 \\
\hline alpha3 & $x$ & $x$ & $\mathrm{~nm}$ & $\mathrm{~nm}$ & $\mathrm{~nm}$ & $x$ & $\mathrm{~nm}$ & $\mathrm{~nm}$ & $x$ & gd 18-30 & Maclntyre et al. 2002 \\
\hline alpha3 & $x$ & - & - & $x$ & $x$ & $=$ & - & - & - & gd 80-270 & Pfarrer et al. 2003 \\
\hline alpha4 & $x$ & - & - & $x$ & $x$ & $=$ & - & - & $x$ & gd 80-270 & Pfarrer et al. 2003 \\
\hline alpha5 & $\mathrm{nm}$ & $\mathrm{nm}$ & $\mathrm{nm}$ & $\mathrm{nm}$ & $x$ & - & $\mathrm{nm}$ & $\mathrm{nm}$ & $\mathrm{nm}$ & gd 14-21 & MacLaren \& Wildeman 1995 \\
\hline alpha5 & $x$ & - & - & $x$ & $x$ & $=$ & - & - & $x$ & gd 80-270 & Pfarrer et al. 2003 \\
\hline alpha6 & $x$ & $x$ & $\mathrm{~nm}$ & $\mathrm{~nm}$ & $\mathrm{~nm}$ & $x$ & $\mathrm{~nm}$ & $\mathrm{~nm}$ & $x$ & gd 18-30 & Macintyre et al. 2002 \\
\hline alpha6 & $x$ & $x$ & - & $x$ & $x$ & $x$ & - & $x$ & $x$ & gd $80-270$ & Pfarrer et al. 2003 \\
\hline alphaV & $x$ & - & - & $x$ & - & $\cdot$ & - & - & - & gd 80-270 & Pfarrer et al. 2003 \\
\hline beta1 & $\mathrm{nm}$ & $\mathrm{nm}$ & $\mathrm{nm}$ & $\mathrm{nm}$ & $x$ & $x$ & $x$ & $x$ & $\mathrm{~nm}$ & gd 14-21 & MacLaren \& Wildeman 1995 \\
\hline beta1 & $x$ & $x$ & $\mathrm{~nm}$ & $\mathrm{~nm}$ & $\mathrm{~nm}$ & $x$ & $\mathrm{~nm}$ & $x$ & $x$ & gd 18-30 & Maclntyre et al. 2002 \\
\hline beta1 & $x$ & $x$ & - & $x$ & $x$ & $x$ & - & $x$ & $x$ & gd 80-270 & Pfarrer et al. 2003 \\
\hline beta1 & $x$ & $x$ & $x$ & $\mathrm{~nm}$ & $x$ & $x$ & $x$ & $x$ & $\mathrm{~nm}$ & gd 80-270 & Bridger et al. 2008 \\
\hline beta3 & $x$ & - & - & $x$ & - & - & - & - & - & gd 80-270 & Pfarrer et al. 2003 \\
\hline beta 4 & $x$ & - & - & $x$ & - & - & - & - & - & gd 80-270 & Pfarrer et al. 2003 \\
\hline
\end{tabular}

MS: maternal stroma; ME: maternal epithelium; MBM: maternal basement membrane; MV: maternal vessels; FS: fetal stroma; UTC: uninuclear trophoblast cell; FBM: fetal basement membrane; TGC: trophoblast giant cell; FV: fetal vessel; gd: gestational day; gm: gestational month; nm: not mentioned

${ }^{1}$ expression only after gd $60 ;{ }^{2}$ expression increase over the course of gestation; ${ }^{3}$ expression decrease shortly before term. 
Table 1. (continued)

\begin{tabular}{|c|c|c|c|c|c|c|c|c|c|}
\hline \multirow{2}{*}{$\frac{\text { Protein }}{\text { MMPs }}$} & \multicolumn{3}{|c|}{ Maternal Localisation } & \multicolumn{4}{|c|}{ Fetal Localisation } & \multirow[b]{2}{*}{ time frame } & \multirow[b]{2}{*}{ Ref. } \\
\hline & MS & ME & MV & FS & UTC & TGC & $\mathrm{FV}$ & & \\
\hline MMP2 & $x$ & $x$ & $x$ & $x$ & $x^{4}$ & - & $x$ & gm 1-9 & Walter \& Boos 2001 \\
\hline MMP2 & $x$ & - & $x$ & $x^{5}$ & - & - & $x$ & $\operatorname{gm} 3-9$ & Dilly et al. 2011 \\
\hline MMP2 & $x^{2}$ & - & $\mathrm{nm}$ & $\mathrm{nm}$ & $x^{2}$ & $x^{6}$ & $\mathrm{~nm}$ & gd 50-275 & Mishra et al. 2012 \\
\hline MMP9 & $x$ & $\mathrm{x}$ & $x$ & - & - & - & $\mathrm{x}$ & gm 1-9 & Walter \& Boos 2001 \\
\hline MMP14 & $x^{7}$ & $x^{7}$ & - & $x^{2,5}$ & $x^{4}$ & - & $x$ & gm 3-9 & Dilly et al. 2011 \\
\hline MMP14 & $x^{2}$ & $x^{2}$ & $\mathrm{~nm}$ & $\mathrm{~nm}$ & $x^{2}$ & $x^{2}$ & $\mathrm{~nm}$ & gd 50-275 & Mishra et al. 2012 \\
\hline MMP14 & - & $x^{3}$ & - & - & - & - & $x$ & 12 days bevor calving & Streyl et al. 2012 \\
\hline TIMP1 & - & $x$ & - & $x$ & $x$ & $\mathrm{x}$ & - & 12 days bevor calving & Streyl et al. 2012 \\
\hline TIMP2 & - & - & - & - & - & $x$ & - & gm 1-9 & Walter \& Boos 2001 \\
\hline TIMP2 & - & - & - & - & - & $x$ & - & gm 3-9 & Dilly et al. 2011 \\
\hline EMMPRIN & - & $x^{2}$ & $\mathrm{~nm}$ & $\mathrm{~nm}$ & $x^{2}$ & $x^{2}$ & $\mathrm{~nm}$ & gd 50-275 & Mishra et al. 2012 \\
\hline GF & MS & ME & MV & FS & UTC & TGC & $\mathrm{FV}$ & time frame & Ref. \\
\hline FGF1 & $x$ & $x$ & - & $x$ & $x$ & $x^{i m, m}$ & - & gd $150-270$ & Pfarrer et al. 2006a \\
\hline FGF2 & $x$ & $x$ & - & $x$ & $x^{3}$ & $x^{i m, 3}$ & - & & \\
\hline FGF7 & - & $x^{6}$ & $\mathrm{x}$ & & $\mathrm{x}$ & $x^{\text {im }}$ & $x$ & & \\
\hline FGFR & $\mathrm{x}$ & - & $x$ & $x$ & $x$ & $x^{\mathrm{im}}$ & $x$ & & \\
\hline FGF1 & - & $x^{7}$ & $x^{4}$ & - & - & $x^{i m}$ & $x^{4}$ & & \\
\hline FGF2 & - & $x^{3}$ & $x^{4}$ & - & - & $x^{i m, 3}$ & $x^{4}$ & & \\
\hline FGF7 & $x$ & $x^{6,8}$ & $x^{6}$ & - & - & $x^{i m, 3}$ & $x^{6}$ & & \\
\hline FGFR & $x^{6,8}$ & $x^{6,8}$ & - & - & - & $x^{i m, 3}$ & - & & \\
\hline FGF2IIIb & $x^{6,8}$ & $x^{6,8}$ & - & - & - & $x^{i m, 3}$ & - & & \\
\hline FGF2IIIC & $x^{6,8}$ & $x^{6,8}$ & - & - & - & $x^{i m, 3}$ & - & & \\
\hline VEGF & $x$ & - & - & $\mathrm{nm}$ & $x$ & $x^{9}$ & $x$ & gd 18-48 & Pfarrer et al. 2006b \\
\hline VEGFR1 & $x$ & $x$ & $x$ & - & $x$ & $x^{9}$ & $x$ & & \\
\hline VEGFR2 & $x$ & $x$ & $x$ & - & $x$ & $x^{9}$ & $\mathrm{x}$ & & \\
\hline VEGF & $x$ & $x$ & $x^{4,11}$ & - & $x$ & $\mathrm{x}$ & $x$ & gd 80 to term & Pfarrer et al. 2006b \\
\hline VEGFR 1 & $x$ & $x^{10}$ & $x$ & - & $x^{10}$ & $x$ & - & & \\
\hline VEGFR2 & $x^{10}$ & $x$ & $x$ & $x^{6}$ & $x$ & - & $x^{6,4}$ & & \\
\hline PAF-R & $x^{4}$ & $x^{8}$ & $x$ & - & - & $x^{i m, 3}$ & $x$ & gd 30 to term & Bucher et al. 2006 \\
\hline PAF-AH & - & $x^{8}$ & $x^{8}$ & - & - & $x^{\lim , 3}$ & $x^{8}$ & & \\
\hline EGFR & - & $x^{12}$ & - & - & $x^{12}$ & $\mathrm{x}$ & - & gd 59-271 & Akbalik \& Ketani 2013 \\
\hline ErbB-2 & $\mathrm{x}$ & $x$ & - & $x^{12}$ & $x^{12}$ & $x^{12}$ & - & & \\
\hline ErbB-3 & $x^{12}$ & $x$ & - & $x^{13}$ & $x$ & $x$ & - & & \\
\hline ErbB-4 & $x^{13}$ & $x^{13}$ & - & $x^{13}$ & $x^{12}$ & $x$ & - & & \\
\hline EGF & - & $x^{12}$ & - & $x^{12}$ & $x^{12}$ & $x^{12}$ & - & & \\
\hline AREG & - & $x^{13}$ & - & $x$ & $\mathrm{x}$ & $x^{12}$ & - & & \\
\hline NRG-1 & - & $x^{13}$ & - & $x$ & $x$ & $x^{13}$ & - & & \\
\hline
\end{tabular}

MS: maternal stroma; ME: maternal epithelium; MV: maternal vessels; FS: fetal stroma; UTC: uninuclear trophoblast cell; TGC: trophoblast giant cell; FV: fetal vessel; gd: gestational day; gm: gestational month; nm: not mentioned; ${ }^{2}$ expression increase over the course of gestation; ${ }^{3}$ expression decrease shortly before term; ${ }^{4}$ expression only at the end of gestation; ${ }^{5}$ expression vanished after normal calving; ${ }^{6}$ very weak immunoreaction; ${ }^{7}$ expression vanished with ongoing gestation; ${ }^{8}$ expression increase shortly before term; ${ }^{9}$ variable expression; ${ }^{10}$ expression only at the begin of gestation; ${ }^{11}$ only migestational (80-120day) expression; ${ }^{12}$ expression decrease over the course of gestation; ${ }^{13}$ expression decrease during the last trimester of gestation; ${ }^{\text {im }}$ immature TGC; ${ }^{m}$ mature TGC. 


\section{Drugs and pathology}

During pregnancy/gestation, drugs or infectious agents can cross the placental barrier and harm placental integrity and the fetus (Giaginis et al. 2012, Johnson et al. 1994). At the same time nutrients have to selectively cross the placental barrier in a controlled manner to ensure optimal embryo growth. Nutrient and drug transport across the human placenta is either mediated by a variety of active transporters or by passive diffusion (Lager \& Powell 2012, Giaginis et al. 2012). In the bovine placenta, proteins responsible for maternal-fetal $\mathrm{Ca}^{2+}$ transport (Sprekeler et al. 2012) and glucose transport have been located on different placental membrane layers (Wooding et al. 2005a). In addition, the prominent drug efflux carrier P-glycoprotein 1 (ABCB1), known for its role in the human placenta (Neumanova et al. 2014), is also functionally expressed in the bovine placenta and in bovine caruncular epithelial cells in vitro, mediating a basal-toapical flux (Waterkotte et al. 2011). Therefore, such endometrial cells might be a proper in vitro model to study drug transport across the placental barrier of cattle. During gestation the bovine placenta is targeted by multiple infectious agents like parasites (Maley et al. 2003), viruses (Swasdipan et al. 2002) or bacteria (Hansen et al. 2011). Such agents have been either suggested as the cause for abortions (de Oliveira et al. 2010) or are also viewed critically in regard to pathogenicity (Agerholm 2013). In rodents and non-human primates, which are commonly employed for risk toxicity assessment, extensive data concerning placental lesions are available (Cline et al. 2013). Similar lesions (e.g. placental necrosis) are also observed in cattle (Gibney et al. 2008). Yet, placental morphological anomalies can also be caused due to non-infectious reasons like twinning (Benirschke 1995) or somatic cell nuclear transfer (SCNT) (Chavatte-Palmer et al. 2012). Furthermore, SCNT pregnancies also differ in their endometrial reaction to the fetus (Bauersachs et al. 2009).

One of the most common conditions occurring in cattle following parturition is RFM, which is associated with increased postpartum disease, decreased milk production and reduced reproductive performance and therefore is economically important (Laven \& Peters 1996). Past studies analyzed a variety of factors in RFM such as apoptosis, and proliferation (Boos et al. 2003a), the expression of singular MMP/TIMP proteins (Dilly et al. 2011) and the change in expression of multiple genes by microarray analysis (Streyl et al. 2012). Very different causes for RFM have been proposed ranging from breed to stress and oxidative damage (Kankofer 2002). In addition, it is known that induction of parturition by different protocols also represents a major cause for RFM (Dilly et al. 2011). Normally at term a massive destruction of collagen and other ECM components accompanies uterine involution and expulsion of fetal membranes (McNaughton \& Murray 2009). Failure of this process appears to be the underlying main cause of RFM, since it was demonstrated that collagenase injection via the umbilical arteries released the retained membranes (Eiler \& Hopkins 1993). Therefore, it stands to reason that the regulation of the activity of endogenous collagenase (MMPs) in the bovine placenta plays a key role in the timely release of fetal membranes. One candidate for such a signal might be 12-oxo-eicosatetraenoic acid (12-oxoETE), which shows a peak concentration in maternal blood prior to release of fetal membranes and induces detachment of cells from culture vessels. In animal experiments injection with 12-oxoETE resulted in rapid release of fetal membranes (Kamada et al. 2012).

\section{New discoveries and major challenges}

In the past years multiple discoveries have been made, providing new information on the development and physiology of the bovine placenta. One such discovery is surely the use of cell lines for mechanistic studies on growth factor action (Hambruch et al. 2009, Dilly et al. 
2010, Hirata et al. 2003b), TGC differentiation (Nakano et al. 2002b, Haeger et al. 2011) and cell-matrix interactions (Bridger et al. 2008). However, one of the main pitfalls is the isolation and characterization of such cell lines, particularly trophoblast lines (Haeger et al. 2011, Shimada et al. 2001, Talbot et al. 2010) due to cross contamination with other placental cell types (Bridger et al. 2007, Feng et al. 2000). Another drawback is the loss of TGC differentiation from such cell lines and the limited options to induce formation in vitro (Hambruch et al. 2009, Haeger et al. 2011, Shimada et al. 2001, Nakano et al. 2002a). More recently 3-dimensional cell culture models (spheroids) have been employed to study TGC formation (Haeger et al. 2011), trophoblast attachment (Sakurai et al. 2012) and endometrial PGF ${ }_{2 \alpha}$ (Prostaglandin $\mathrm{F}_{2 \alpha}$ ) secretion (Yamauchi et al. 2003). Yet, the use of bovine placental cell lines might still prove to be a valuable tool in the future, as important observations in human trophoblast physiology (e.g. syncytialization) have also been made in cell culture systems (Kliman et al. 1986). In addition, studies have been published, which provide clues for further research on placental development including the following: (1) the fact that bovine trophoblast expresses mesenchymal-genes after attachment to the endometrium (Yamakoshi et al. 2012), which represents a dramatic change to mid-gestation as far as vimentin is concerned (Haeger et al. 2011), underlining the plasticity of bovine trophoblast cells during different stages of gestation; and (2) the hypothesis that endogenous retroviruses are evolutionary driving forces for placental structure, TGC differentiation and cell fusion in the bovine placenta (Koshi et al. 2012, Spencer \& Palmarini 2012, Black et al. 2010, Nakaya et al. 2013). Furthermore, future work in the field of placental development should also be directed at the cellular effects of trophoblastic glycoproteins like pregnancy-associated glycoproteins (PAG), and their functional implications at the feto-maternal interface (Wooding et al. 2005b).

\section{Conclusions}

Due to the economic importance of bovine reproduction extensive data are available on the development of the placenta in cattle. Nevertheless, even though new intriguing facts have been discovered, the understanding of economically important diseases like RFM still poses a major challenge. A wide variety of important questions are available for future research studies to be undertaken by bovine and/or ruminant placentologists, since it has become clear that placental physiology and pathology are important. Despite new technological opportunities (e.g. microarray analysis), techniques such as electron microscopy have yielded an incredible amount of valuable data (Wathes \& Wooding 1980, Wooding et al. 1994, Leiser 1975, Leiser et al. 1997) and could still be employed in future research. Interestingly, adaptive angiogenesis in the ruminant placenta (Krebs et al. 1997) shows remarkable similarities to adaptive angiogenesis in fetal villi in placentas of heavy smokers (Pfarrer et al. 1999). Therefore, researchers working predominantly on human placentation might also consider mechanisms associated with bovine placentation since the villous feto-maternal interdigitation and the branching of villi is similar to human placental villi.

\section{Acknowledgements}

The excellent technical assistance of Mrs. I. Blume, D. Walther, M. Gaehle and K. Rohn is gratefully acknowledged. The work is funded by a grant from the German Research Foundation (Deutsche Forschungsgemeinschaft, DFG). The scientific work of all current and former doctoral students of the group is also kindly acknowledged. 


\section{References}

Agerholm JS 2013 Coxiella burnetii associated reproductive disorders in domestic animals-a critical review. Acta Vet Scand 5513.

Akbalik ME \& Ketani MA 2013 Expression of epidermal growth factor receptors and epidermal growth factor, amphiregulin and neuregulin in bovine uteroplacental tissues during gestation. Placenta 34 1232-1242.

Assis Neto AC, Pereira FT, Santos TC, Ambrosio CE, Leiser R \& Miglino MA 2010 Morpho-physical recording of bovine conceptus (Bos indicus) and placenta from days 20 to 70 of pregnancy. Reprod Domest Anim 45 760-772.

Atkinson BA, King GJ \& Amoroso EC 1984 Development of the caruncular and intercaruncular regions in the bovine endometrium. Biol Reprod 30 763-774.

Baba K, Nakaya Y, Shojima T, Muroi Y, Kizaki K, Hashizume K, Imakawa K \& Miyazawa T 2011 Identification of novel endogenous betaretroviruses which are transcribed in the bovine placenta. J Virol 85 1237-1245.

Bai H, Sakurai T, Kim MS, Muroi Y, Ideta A, Aoyagi Y, Nakajima H, Takahashi M, Nagaoka K \& Imakawa K 2009 Involvement of GATA transcription factors in the regulation of endogenous bovine interferon-tau gene transcription. Mol Reprod Dev 76 1143-1152.

Bauersachs S, Ulbrich SE, Zakhartchenko V, Minten M, Reichenbach M, Reichenbach HD, Blum H, Spencer TE \& Wolf E 2009 The endometrium responds differently to cloned versus fertilized embryos. Proc Natl Acad Sci U S A 106 5681-5686.

Benirschke K 1995 The biology of the twinning process: how placentation influences outcome. Semin Perinatol 19 342-350.

Bjorkman NH 1969 Light and electron microscopic studies on cellular alterations in the normal bovine placentome. Anat Rec 163 17-29.

Black SG, Arnaud F, Burghardt RC, Satterfield MC, Fleming JA, Long CR, Hanna C, Murphy L, Biek R, Palmarini M \& Spencer TE 2010 Viral particles of endogenous betaretroviruses are released in the sheep uterus and infect the conceptus trophectoderm in a transspecies embryo transfer model. J Virol 84 9078-9085.

Boos A 2000 Immunohistochemical assessment of collagen types I, III, IV and VI in biopsy samples of the bovine uterine wall collected during the oestrous cycle. Cells Tissues Organs 167 225-238.

Boos A, Janssen V \& Mulling C 2003a Proliferation and apoptosis in bovine placentomes during pregnancy and around induced and spontaneous parturition as well as in cows retaining the fetal membranes. Reproduction 126 469-480.

Boos A, Kohtes J, Stelljes A, Zerbe H \& Thole HH 2000 Immunohistochemical assessment of progesterone, oestrogen and glucocorticoid receptors in bovine placentomes during pregnancy, induced parturition, and after birth with or without retention of fetal membranes. J Reprod Fertil 120 351-360.

Boos A, Stelljes A \& Kohtes J 2003b Collagen types I, III and IV in the placentome and interplacentomal maternal and fetal tissues in normal cows and in cattle with retention of fetal membranes. Cells Tissues Organs 174 170-183.

Bridger PS, Haupt S, Klisch K, Leiser R, Tinneberg HR \& Pfarrer C 2007 Validation of primary epitheloid cell cultures isolated from bovine placental caruncles and cotyledons. Theriogenology 68 592-603.

Bridger PS, Haupt S, Leiser R, Johnson GA, Burghardt RC, Tinneberg HR \& Pfarrer C 2008 Integrin activation in bovine placentomes and in caruncular epithelial cells isolated from pregnant cows. Biol Reprod 79 274-282.

Bucher K, Leiser R, Tiemann U \& Pfarrer C 2006 Plateletactivating factor receptor (PAF-R) and acetylhydrolase (PAF-AH) are co-expressed in immature bovine trophoblast giant cells throughout gestation, but not at parturition. Prostaglandins Other Lipid Mediat 79 74-83.

Burghardt RC, Johnson GA, Jaeger LA, Ka H, Garlow JE, Spencer TE \& Bazer FW 2002 Integrins and extracellular matrix proteins at the maternal-fetal interface in domestic animals. Cells Tissues Organs 172 202-217.

Buse E, Haeger JD, Svensson-Arvelund J, Markert UR, Faas MM, Ernerudh J, Dixon D, Cline JM \& Pfarrer C 2013 The Placenta in Toxicology. Part I: Animal Models in Toxicology: Placental Morphology and Tolerance Molecules in the Cynomolgus Monkey (Macaca fascicularis). Toxicol Pathol.

Cauwe B \& Opdenakker G 2010 Intracellular substrate cleavage: a novel dimension in the biochemistry, biology and pathology of matrix metalloproteinases. Crit Rev Biochem Mol Biol 45 351-423.

Chavatte-Palmer P, Camous S, Jammes H, Le Cleac'h N, Guillomot M \& Lee RS 2012 Review: Placental perturbations induce the developmental abnormalities often observed in bovine somatic cell nuclear transfer. Placenta 33 Suppl S99-S104.

Clark IM, Swingler TE, Sampieri CL \& Edwards DR 2008 The regulation of matrix metalloproteinases and their inhibitors. Int J Biochem Cell Biol 40 1362-1378.

Cline JM, Dixon D, Ernerudh J, Faas MM, Gohner C, Hager JD, Markert UR, Pfarrer C, Svensson-Arvelund J \& Buse E 2013 The Placenta in Toxicology. Part III: Pathologic Assessment of the Placenta. Toxicol Pathol.

de Oliveira VS, Alvarez-Garcia G, Ortega-Mora LM, Borges LM \& da Silva AC 2010 Abortions in bovines and Neospora caninum transmission in an embryo transfer center. Vet Parasitol 173 206-210.

Degrelle SA, Murthi P, Evain-Brion D, Fournier T \& Hue I 2011 Expression and localization of DLX3, PPARG and SP1 in bovine trophoblast during binucleated cell differentiation. Placenta 32 917-920.

Dilly M, Hambruch N, Haeger JD \& Pfarrer C 2010 Epidermal growth factor (EGF) induces motility and upregulates MMP-9 and TIMP-1 in bovine trophoblast cells. Mol Reprod Dev 77 622-629.

Dilly M, Hambruch N, Shenavai S, Schuler G, Froehlich R, Haeger JD, Ozalp GR \& Pfarrer C 2011 Expression of matrix metalloproteinase (MMP)-2, MMP-14 and tissue inhibitor of matrix metalloproteinase (TIMP)-2 during bovine placentation and at term with or without placental retention. Theriogenology 75 1104-1114. 
Egeblad M \& Werb Z 2002 New functions for the matrix metalloproteinases in cancer progression. Nat Rev Cancer 2 161-174.

Eiler H \& Hopkins FM 1993 Successful treatment of retained placenta with umbilical cord injections of collagenase in cows. J Am Vet Med Assoc 203 436-443.

Fanjul-Fernandez M, Folgueras AR, Cabrera S \& LopezOtin C 2010 Matrix metalloproteinases: evolution, gene regulation and functional analysis in mouse models. Biochim Biophys Acta 1803 3-19.

Feng S, Peter AT \& Asem EK 2000 Endothelial-like cells from the bovine placental cotyledon. In Vitro Cell Dev Biol Anim 36 527-531.

Ferretti C, Bruni L, Dangles-Marie V, Pecking AP \& Bellet D 2007 Molecular circuits shared by placental and cancer cells, and their implications in the proliferative, invasive and migratory capacities of trophoblasts. Hum Reprod Update 13 121-141.

Giaginis C, Theocharis S \& Tsantili-Kakoulidou A 2012 Current toxicological aspects on drug and chemical transport and metabolism across the human placental barrier. Expert Opin Drug Metab Toxicol 8 1263-1275.

Gibney EH, Kipar A, Rosbottom A, Guy CS, Smith RF, Hetzel U, Trees AJ \& Williams DJ 2008 The extent of parasite-associated necrosis in the placenta and foetal tissues of cattle following Neospora caninum infection in early and late gestation correlates with foetal death. Int J Parasitol 38 579-588.

Greenstein JS, Murray RW \& Foley RC 1958 Observations on the morphogenesis and histochemistry of the bovine preattachment placenta between 16 and 33 days of gestation. Anat Rec 132 321-341.

Grosser O 1927 Vergeichende Plazentationslehre. Frühentwicklung Eihautbildung und Placentation des Menschen und der Säugetiere München: Verlag von Jf Bergmann:95-174.

Guillomot M 1999 Changes in extracellular matrix components and cytokeratins in the endometrium during goat implantation. Placenta 20 339-345.

Haeger JD, Hambruch N, Dilly M, Froehlich R \& Pfarrer C 2011 Formation of bovine placental trophoblast spheroids. Cells Tissues Organs 193 274-284.

Hambruch N, Haeger JD, Dilly M \& Pfarrer C 2009 EGF stimulates proliferation in the bovine placental trophoblast cell line F3 via Ras and MAPK. Placenta.

Hansen MS, Rodolakis A, Cochonneau D, Agger JF, Christoffersen AB, Jensen TK \& Agerholm JS 2011 Coxiella burnetii associated placental lesions and infection level in parturient cows. Vet J 190 e135-139.

Hemberger M, Hughes M \& Cross JC 2004 Trophoblast stem cells differentiate in vitro into invasive trophoblast giant cells. Dev Biol 271 362-371.

Hirata $M$, Sato T, Tsumagari $M$, Hashizume $K$ \& Ito A 2003a Discoordinate regulation of expression of matrix metalloproteinases and tissue inhibitor of metalloproteinases-3 in bovine endometrial stromal cells on type-l collagen gel. Biol Pharm Bull 26 1013-1017.

Hirata M, Sato T, Tsumagari M, Shimada A, Nakano $H$, Hashizume K \& Ito A 2003b Differential regulation of the expression of matrix metalloproteinases and tissue inhibitors of metalloproteinases by cytokines and growth factors in bovine endometrial stromal cells and trophoblast cell line BT-1 in vitro. Biol Reprod 68 1276-1281.

Hu D \& Cross JC 2010 Development and function of trophoblast giant cells in the rodent placenta. Int J Dev Biol 54 341-354.

Johnson CT, Lupson GR \& Lawrence KE 1994 The bovine placentome in bacterial and mycotic abortions. Vet Rec 134 263-266.

Johnson GA, Burghardt RC, Joyce MM, Spencer TE, Bazer FW, Gray CA \& Pfarrer C 2003 Osteopontin is synthesized by uterine glands and a $45-\mathrm{kDa}$ cleavage fragment is localized at the uterine-placental interface throughout ovine pregnancy. Biol Reprod 69 92-98.

Kalluri R \& Zeisberg M 2006 Fibroblasts in cancer. Nat Rev Cancer 6 392-401.

Kamada H, Matsui Y, Sakurai Y, Tanigawa T, Itoh M, Kawamoto S, Kai K, Sasaki T, Takahashi K, Hayashi M, Takayama Y, Nakamura M, Kadokawa H, Ueda Y, Sutoh M \& Murai M 2012 Twelve oxo-eicosatetraenoic acid induces fetal membrane release after delivery in cows. Placenta 33 106-113.

Kankofer M 2002 8-iso-prostaglandin F2alpha as a marker of tissue oxidative damage in bovine retained placenta. Prostaglandins Other Lipid Mediat 70 51-59.

Khatri P, Hoffmann B \& Schuler G 2013 Androgen receptor is widely expressed in bovine placentomes and upregulated during differentiation of bovine trophoblast giant cells. Placenta 34 416-423.

Kizaki K, Ushizawa K, Takahashi T, Yamada O, Todoroki J, Sato T, Ito A \& Hashizume K 2008 Gelatinase (MMP-2 and -9) expression profiles during gestation in the bovine endometrium. Reprod Biol Endocrinol 666.

Kliman HJ, Nestler JE, Sermasi E, Sanger JM \& Strauss JF, 3rd 1986 Purification, characterization, and in vitro differentiation of cytotrophoblasts from human term placentae. Endocrinology 118 1567-1582.

Klisch K, Boos A, Friedrich M, Herzog K, Feldmann M, Sousa N, Beckers J, Leiser R \& Schuler G 2006 The glycosylation of pregnancy-associated glycoproteins and prolactinrelated protein-I in bovine binucleate trophoblast giant cells changes before parturition. Reproduction 132 791-798.

Klisch K, Hecht W, Pfarrer C, Schuler G, Hoffmann B \& Leiser R 1999a DNA content and ploidy level of bovine placentomal trophoblast giant cells. Placenta 20 451-458.

Klisch K, Pfarrer C, Schuler G, Hoffmann B \& Leiser R 1999b Tripolar acytokinetic mitosis and formation of feto-maternal syncytia in the bovine placentome: different modes of the generation of multinuclear cells. Anat Embryol (Berl) 200 229-237.

Koshi K, Suzuki Y, Nakaya Y, Imai K, Hosoe M, Takahashi T, Kizaki K, Miyazawa T \& Hashizume K 2012 Bovine trophoblastic cell differentiation and binucleation involves enhanced endogenous retrovirus element expression. Reprod Biol Endocrinol 1041.

Koshi K, Ushizawa K, Kizaki K, Takahashi T \& Hashizume K 2011 Expression of endogenous retrovirus-like transcripts in bovine trophoblastic cells. Placenta 32 493-499. 
Krebs C, Longo LD \& Leiser R 1997 Term ovine placental vasculature: comparison of sea level and high altitude conditions by corrosion cast and histomorphometry. Placenta 18 43-51.

Lager S \& Powell TL 2012 Regulation of nutrient transport across the placenta. J Pregnancy 2012179827.

Laven RA \& Peters AR 1996 Bovine retained placenta: aetiology, pathogenesis and economic loss. Vet Rec 139 465-471.

Leiser R 1975 [Development of contact between trophoblast and uterine epithelium during the early stages on implantation in the cow]. Zentralb/ Veterinarmed C 4 63-86.

Leiser R, Krebs C, Klisch K, Ebert B, Dantzer V, Schuler G \& Hoffmann B 1997 Fetal villosity and microvasculature of the bovine placentome in the second half of gestation. J Anat 191 ( Pt 4) 517-527.

MacIntyre DM, Lim HC, Ryan K, Kimmins S, Small JA \& MacLaren LA 2002 Implantation-associated changes in bovine uterine expression of integrins and extracellular matrix. Biol Reprod 66 1430-1436.

MacLaren LA \& Wildeman AG 1995 Fibronectin receptors in preimplantation development: cloning, expression, and localization of the alpha 5 and beta 1 integrin subunits in bovine trophoblast. Biol Reprod 53 153-165.

Madeja ZE, Sosnowski J, Hryniewicz K, Warzych E, Pawlak P, Rozwadowska N, Plusa B \& Lechniak D 2013 Changes in sub-cellular localisation of trophoblast and inner cell mass specific transcription factors during bovine preimplantation development. BMC Dev Biol 1332.

Maley SW, Buxton D, Rae AG, Wright SE, Schock A, Bartley PM, Esteban-Redondo I, Swales C, Hamilton CM, Sales J \& Innes EA 2003 The pathogenesis of neosporosis in pregnant cattle: inoculation at mid-gestation. J Comp Pathol 129 186-195.

McEwan M, Lins RJ, Munro SK, Vincent ZL, Ponnampalam AP \& Mitchell MD 2009 Cytokine regulation during the formation of the fetal-maternal interface: focus on cell-cell adhesion and remodelling of the extra-cellular matrix. Cytokine Growth Factor Rev 20 241-249.

McNaughton AP \& Murray RD 2009 Structure and function of the bovine fetomaternal unit in relation to the causes of retained fetal membranes. Vet Rec 165 615-622.

Mishra B, Kizaki K, Koshi K, Ushizawa K, Takahashi T, Hosoe M, Sato T, Ito A \& Hashizume K 2012 Expression of extracellular matrix metalloproteinase inducer (EMMPRIN) and its expected roles in the bovine endometrium during gestation. Domest Anim Endocrinol 42 63-73.

Murray MJ \& Lessey BA 1999 Embryo implantation and tumor metastasis: common pathways of invasion and angiogenesis. Semin Reprod Endocrinol 17 275-290.

Nakano H, Shimada A, Imai K, Takahashi T \& Hashizume K 2002a Association of Dolichos biflorus lectin binding with full differentiation of bovine trophoblast cells. Reproduction 124 581-592.

Nakano H, Shimada A, Imai K, Takezawa T, Takahashi T \& Hashizume K 2002b Bovine trophoblastic cell differentiation on collagen substrata: formation of binucleate cells expressing placental lactogen. Cell Tissue Res 307 225-235.
Nakaya Y, Koshi K, Nakagawa S, Hashizume K \& Miyazawa T 2013 Fematrin-1 is involved in fetomaternal cell-to-cell fusion in Bovinae placenta and has contributed to diversity of ruminant placentation. J Virol 87 10563-10572.

Neumanova Z, Cerveny L, Ceckova M \& Staud F 2014 Interactions of tenofovir and tenofovir disoproxil fumarate with drug efflux transporters ABCB1, ABCG2, and $A B C C 2$, role in transport across the placenta. AIDS 28 9-17.

Pennington KA \& Ealy AD 2012 The expression and potential function of bone morphogenetic proteins 2 and 4 in bovine trophectoderm. Reprod Biol Endocrinol 1012.

Pfarrer C, Hirsch P, Guillomot M \& Leiser R 2003 Interaction of integrin receptors with extracellular matrix is involved in trophoblast giant cell migration in bovine placentomes. Placenta 24 588-597.

Pfarrer C, Macara L, Leiser R \& Kingdom J 1999 Adaptive angiogenesis in placentas of heavy smokers. Lancet 354303.

Pfarrer C, Weise S, Berisha B, Schams D, Leiser R, Hoffmann B \& Schuler G 2006a Fibroblast growth factor (FGF)-1, FGF2, FGF7 and FGF receptors are uniformly expressed in trophoblast giant cells during restricted trophoblast invasion in cows. Placenta 27 758-770.

Pfarrer CD, Ruziwa SD, Winther H, Callesen H, Leiser R, Schams D \& Dantzer V 2006b Localization of vascular endothelial growth factor (VEGF) and its receptors VEGFR-1 and VEGFR-2 in bovine placentomes from implantation until term. Placenta 27 889-898.

Ravelich SR, Breier BH, Reddy S, Keelan JA, Wells DN, Peterson AJ \& Lee RS 2004 Insulin-like growth factor-I and binding proteins 1,2 , and 3 in bovine nuclear transfer pregnancies. Biol Reprod 70 430-438.

Ravelich SR, Shelling AN, Wells DN, Peterson AJ, Lee RS, Ramachandran A \& Keelan JA 2006 Expression of TGF-beta1, TGF-beta2, TGF-beta3 and the receptors TGF-betaRI and TGF-betaRII in placentomes of artificially inseminated and nuclear transfer derived bovine pregnancies. Placenta 27 307-316.

Sakurai T, Bai H, Bai R, Arai M, Iwazawa M, Zhang J, Konno T, Godkin JD, Okuda K \& Imakawa K 2012 Coculture system that mimics in vivo attachment processes in bovine trophoblast cells. Biol Reprod 8760.

Schuler G, Greven H, Kowalewski MP, Doring B, Ozalp GR \& Hoffmann B 2008 Placental steroids in cattle: hormones, placental growth factors or by-products of trophoblast giant cell differentiation? Exp Clin Endocrinol Diabetes 116 429-436.

Shimada A, Nakano H, Takahashi T, Imai K \& Hashizume K 2001 Isolation and characterization of a bovine blastocystderived trophoblastic cell line, BT-1: development of a culture system in the absence of feeder cell. Placenta 22 652-662.

Spencer TE \& Palmarini M 2012 Endogenous retroviruses of sheep: a model system for understanding physiological adaptation to an evolving ruminant genome. / Reprod Dev 58 33-37.

Sprekeler N, Kowalewski MP \& Boos A 2012 TRPV6 and Calbindin-D9k-expression and localization in the bovine uterus and placenta during pregnancy. Reprod Biol Endocrinol 1066. 
Streyl D, Kenngott R, Herbach N, Wanke R, Blum H, Sinowatz F, Wolf E, Zerbe H \& Bauersachs S 2012 Gene expression profiling of bovine peripartal placentomes: detection of molecular pathways potentially involved in the release of foetal membranes. Reproduction 143 85-105.

Sugawara K, Kizaki K, Herath CB, Hasegawa Y \& Hashizume K 2010 Transforming growth factor beta family expression at the bovine feto-maternal interface. Reprod Biol Endocrinol 8120.

Swasdipan S, McGowan M, Phillips N \& Bielefeldt-Ohmann H 2002 Pathogenesis of transplacental virus infection: pestivirus replication in the placenta and fetus following respiratory infection. Microb Pathog 32 49-60.

Taipale J \& Keski-Oja J 1997 Growth factors in the extracellular matrix. FASEB J 11 51-59.

Talbot NC, Powell AM, Caperna TJ \& Garrett WM 2010 Proteomic analysis of the major cellular proteins of bovine trophectoderm cell lines derived from IVP, parthenogenetic and nuclear transfer embryos: Reduced expression of annexins I and II in nuclear transfer-derived cell lines. Anim Reprod Sci 120 187-202.

Walter I \& Boos A 2001 Matrix metalloproteinases (MMP-2 and MMP-9) and tissue inhibitor-2 of matrix metalloproteinases (TIMP-2) in the placenta and interplacental uterine wall in normal cows and in cattle with retention of fetal membranes. Placenta 22 473-483.

Waterkotte B, Hambruch N, Doring B, Geyer J, Tinneberg HR \& Pfarrer C 2011 P-glycoprotein is functionally expressed in the placenta-derived bovine caruncular epithelial cell line 1 (BCEC-1). Placenta 32 146-152.

Wathes DC \& Wooding FB 1980 An electron microscopic study of implantation in the cow. Am J Anat 159 285-306.
Wimsatt WA 1951 Observations on the morphogenesis, cytochemistry, and significance of the binocleate giant cells of the placenta of ruminants. Am J Anat 89 233-281.

Wooding FB 1992 Current topic: the synepitheliochorial placenta of ruminants: binucleate cell fusions and hormone production. Placenta 13 101-113.

Wooding FB, Fowden AL, Bell AW, Ehrhardt RA, Limesand SW \& Hay WW 2005a Localisation of glucose transport in the ruminant placenta: implications for sequential use of transporter isoforms. Placenta 26 626-640.

Wooding FB, Morgan G, Brandon MR \& Camous S 1994 Membrane dynamics during migration of placental cells through trophectodermal tight junctions in sheep and goats. Cell Tissue Res 276 387-397.

Wooding FB, Roberts RM \& Green JA 2005b Light and electron microscope immunocytochemical studies of the distribution of pregnancy associated glycoproteins (PAGs) throughout pregnancy in the cow: possible functional implications. Placenta 26 807-827.

Yamada O, Todoroki J, Takahashi T \& Hashizume K 2002 The dynamic expression of extracellular matrix in the bovine endometrium at implantation. J Vet Med Sci 64 207-214.

Yamakoshi S, Bai R, Chaen T, Ideta A, Aoyagi Y, Sakurai T, Konno T \& Imakawa K 2012 Expression of mesenchymalrelated genes by the bovine trophectoderm following conceptus attachment to the endometrial epithelium. Reproduction 143 377-387.

Yamauchi N, Yamada O, Takahashi T, Imai K, Sato T, Ito A \& Hashizume K 2003 A three-dimensional cell culture model for bovine endometrium: regeneration of a multicellular spheroid using ascorbate. Placenta 24 258-269. 